\title{
Flexural Behavior of Post-tensioned Lightweight Concrete Continuous One-Way Slabs
}

\author{
Keun-Hyeok Yang ${ }^{1)}$, Yongjei Lee ${ }^{2), *}\left(\mathbb{D}\right.$, and Dae-Bong Joo ${ }^{3)}$
}

(Received January 7, 2016, Accepted September 9, 2016, Published online October 14, 2016)

\begin{abstract}
In this experimental study, six post-tensioned light weight concrete (LWC) continuous one-way slabs were tested in the following manner: the flexural behaviors of the members were compared with the calculations from the existing standards. The test also examined the effect of prestressing in tendons and proper prestress conditions to reduce the deflection and crack width, and to enhance the flexural capacity and ductility of LWC members. Flexural capacity and stress increments in unbonded tendons of the specimens were compared with those of the simply supported normal and the lightweight concrete members. The suggested safety limit from the American Concrete Institute (ACI) regulation on the maximum capacity and the stress incremental in unbonded tendons were also compared with the test results under simple and continuous supporting conditions.
\end{abstract}

Keywords: post-tensioned, continuous one-way slab, lightweight concrete, flexural capacity.

\section{Introduction}

Due to many well-known advantageous aspects, researchers have investigated the possibility of light weight concrete (LWC) as a replacement for normal weight concrete (NWC) for structural components. A comparative study on the fracture properties of high-strength concrete with normal aggregate and lightweight aggregate was conducted (Tang et al. 2008). Through the study, the critical stress intensity factor and critical crack tip opening displacement for the doubleparameters model and the fracture energy for a fictitious crack model were examined. Since LWC possesses thermal insulation capacity, it can enhance energy consumption efficiency for commercial and residential heating and cooling systems (Chandra and Berntsson 2003; Kayali 2008). For example, using LWC as a structural material may reduce the overall energy consumption of buildings (Yang 2010). Consequently, LWC has been gathering attention as a potential construction material to minimize long-term carbon dioxide $\left(\mathrm{CO}_{2}\right)$ emissions. On one hand, LWC has shown disadvantages in structural performance due to its relatively low Young's modulus and tensile resistance capacity causing larger deformations and crack width in concrete. By the way, prestressing is highly effective in minimizing cracks and controlling deflections of concrete flexural members (Collins and Mitchell 1991).

\footnotetext{
${ }^{1)}$ Department of Architectural Engineering, Kyonggi University, Suwon 16227, Korea.

${ }^{2)}$ YG Engineering \& Architects, Seoul 06125, Korea.

*Corresponding Author; E-mail: yongjei@gmail.com

${ }^{3)} 4 \mathrm{M}$ Engineering Co., Naju-si, Korea.

Copyright $($ The Author(s) 2016. This article is published with open access at Springerlink.com
}

Introducing a prestressing force to the LWC flexural members can compensate for the reduced serviceability of the members, producing considerable synergistic advantages in structural and environmental aspects. Therefore, a prestressed concrete system with LWC is recognized as a decent solution for creating a suitable structure that can decrease the consumption of the natural resources and reduction in the enormous amount of $\mathrm{CO}_{2}$ emitted from construction and residual environments (Chandra and Berntsson 2003; Oh and Choi 2004).

Most of the research using prestressed concrete flexural members has been conducted with normal weight concrete (NWC) (Warwaruk et al. 1962; Harajli and Kanj 1990; Campbell and Chouinard, 1991; Chakrabrti 1995; Mainsekar and Senthil 2006; Lou and Xiang 2007; Ellobody and Bailey 2008; Cai et al. 2009). Yang and Mun (2013) initiated experimental studies on the flexural capacity of post-tensioned LWC beams. They found the stress increase in the unbonded strands $\left(\Delta f_{p s}\right)$ at the ultimate strength of the posttensioned LWC beam was higher than that of the post-tensioned NWC beams under same reinforcing index values. This indicates that the ACI 318-11 provisions for $\Delta f_{p s}$ would be unconservative for post-tensioned LWC members.

Currently, most codes and recommendations, including American Concrete Institute standards (ACI Committee 318 2011), evaluate the flexural behaviors of the post-tensioned concrete members based on studies with NWC; therefore, there could be a question about how to evaluate the flexural behavior of post-tensioned LWC members. As it is well known, LWC has lower stiffness than NWC. LWC also shows many different material properties from NWC including creep and drying shrinkage deformation. The flexural behaviors of post-tensioned LWC members are distinguished from those of NWC in bending strength, ductility and stress in unbonded strands. 
One of the most important factors in the design of posttensioned flexural members is to evaluate the stress incremental in unbonded tendons to which the sectional strain compatibility condition is not applicable. The stress increase in unbonded tendons is suggested by the member compatibility condition based upon the test results using simply supported NWC beams (ACI Committee 318 2011; Yang et al. 2013). However, when it comes to the LWC, insufficient data have been provided to assure the safety of the existing models and current design standards. For safe design of post-tensioned LWC beams, the effects of variables on the stress incremental in unbonded tendons must be studied under both simple and continuous support conditions. Therefore, the bond reduction coefficients of plastic hinge length proposed to evaluate stress increase in unbonded tendon need to be adjusted in LWC members because the proposed equations are empirically derived using limited test data from the NWC members. However, available test results and information are very rare for LWC flexural members.

In this experimental study, six post-tensioned LWC continuous one-way slabs were tested. For each test parameter, the crack developments, failure modes, load-displacement relation, and load-tendon stress relationship were measured. The ultimate stress and stress incremental of the tendons were compared to the calculation results using the existing standards; ACI 318-11, AASHTO (1998) and CAN3-A23M94. The stress increments of the tendons were also compared to the previous NWC test data generated by Lim et al. (1999). The flexural behaviors of the members were compared using calculations derived from the existing standards (ACI, AASHTO, and CAN3). The tests also examined the effect of prestressing in tendons and proper prestress procedures to reduce the deflection and crack width, and to enhance the flexural capacity and ductility of LWC members. Flexural capacity and stress increment in unbonded tendons of the specimens were compared to those of the simply supported normal and the LWC members. The suggested safety limit from the ACI regulation on the maximum capacity and the stress incremental in unbonded tendons were also compared to the test results under simple and continuous supporting conditions.

\subsection{Significance of Research}

This research provides meaningful test results on the behaviors of the post-tensioned continuous lightweight slabs. Here, the applicability of the stress incremental equations for unbonded tendons suggested by design standards was evaluated. The stress increments in unbonded tendons were also reviewed under simple and continuous support conditions. Authors believe the results can provide basic data for development of a future design manual of post-tensioned continuous lightweight concrete slabs.

\section{Experimental Program}

\subsection{Specimens}

Six LWC one-way continuous slab specimens post-tensioned with unbonded tendons were prepared for flexural tests, as shown in Table 1. The nomenclature for each specimen is shown in Fig. 1. Each specimen had three supports with two spans. Two critical parameters affecting the stress increase in unbonded tendons were considered in experiments: span-to-effective tendon depth ratio $\left(L / d_{p}\right)$ in Group 1; and steel ratio in member section $\left(\rho_{s}\right)$ in Group 2.

As known well from the study by Mojtahedi and Gamble (1978), $L / d_{p}$ of the concrete member can affect the stress in tendons. ACI 318 equation (18-4) overestimates $\Delta f_{p s}$ in NWC members when $L / d_{p}$ is greater than 35 . In this study, $L /$ $d_{p}$ varies from 25,35 , and 45 to evaluate the stress changes in tendons. It was Warwaruk et al. (1962) who conducted an

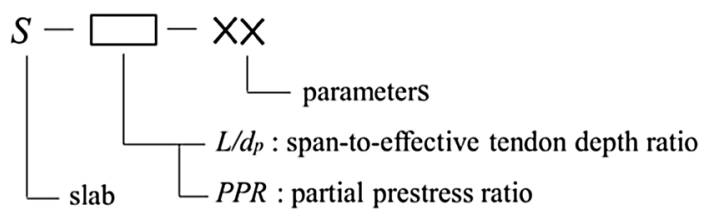

Fig. 1 Specimen nomenclature.

Table 1 Specimen details (unit: $\mathrm{mm}$ ).

\begin{tabular}{|c|c|c|c|c|c|c|c|c|c|c|c|}
\hline Group & Specimen & Load Type & $b$ & $h$ & $\begin{array}{l}L \text { (one } \\
\text { span) }\end{array}$ & $L / d_{p}$ & $P P R$ & $\rho_{s}$ & $\rho_{p}$ & $f_{p e} / f_{p u}$ & $e$ \\
\hline \multirow[t]{3}{*}{1} & $S-L / d_{p}-25$ & \multirow[t]{6}{*}{ Uniform } & \multirow[t]{6}{*}{600} & \multirow[t]{6}{*}{125} & 2400 & 25 & \multirow[t]{3}{*}{0.792} & \multirow[t]{3}{*}{0.00247} & \multirow[t]{6}{*}{0.00206} & \multirow[t]{6}{*}{0.6} & \multirow[t]{3}{*}{33.1} \\
\hline & $S-L / d_{p}-35$ & & & & 3400 & 35 & & & & & \\
\hline & $S-L / d_{p}-45$ & & & & \multirow[t]{4}{*}{4300} & \multirow[t]{4}{*}{45} & & & & & \\
\hline \multirow[t]{3}{*}{2} & $S-P P R-0.5$ & & & & & & 0.884 & 0.00123 & & & 33.2 \\
\hline & S-PPR-1.0 & & & & & & 0.792 & 0.00247 & & & 33.1 \\
\hline & $S-P P R-1.5$ & & & & & & 0.718 & 0.00370 & & & 32.9 \\
\hline
\end{tabular}

$b$ member width, $h$ member height, $e$ eccentricity of prestressing strands, $\rho_{s}$ ratio of steel, $\rho_{p}$ ratio of tendon, $d_{p}$ effective depth of prestressing strands.

$P P R$ (partial prestressing ratio) $=A_{p} f_{p e}\left(A_{p} f_{p e}+A_{s} f_{y}\right)$, where $f_{p e}$ effective prestress, $A_{p}$ sectional area of prestressing steel, $f_{y}$ yield stress of steel, $A_{s}$ sectional area of steel. 
experiment about the loading pattern for the first time. Harajli and Kanj (1990) found the length of the plastic hinges of beams, as well as the stress in tendons, can be changed according to the loading patterns. When it comes to continuous slabs, a uniform loading method has been suggested for ideal member behaviors (Burns et al. 1978), so the use of uniformly distributed loading was applied in this test.

Group 1 consists of three continuous one-way slabs receiving uniformly distributed load whose $L / d_{p}$ ranges from
25,35 and 45 . The ACI 318-11 requires at least $0.4 \%$ reinforcement of the cross section between the flexural tension face and center of gravity of gross section $\left(A_{c t}\right)$. Three slabs in Group 2 receiving uniformly distributed load have three different $\rho_{s}$ 's with the same span and the $L / d_{p}$; half of the ACI requirement $(S-P P R-0.5)$, same with the requirement $(S-P P R-1.0)$, and $50 \%$ more than the requirement (SPPR-1.5). In all specimens, identical three-strand tendons with $2050 \mathrm{MPa}$ tensile strength were used. D10 and D6

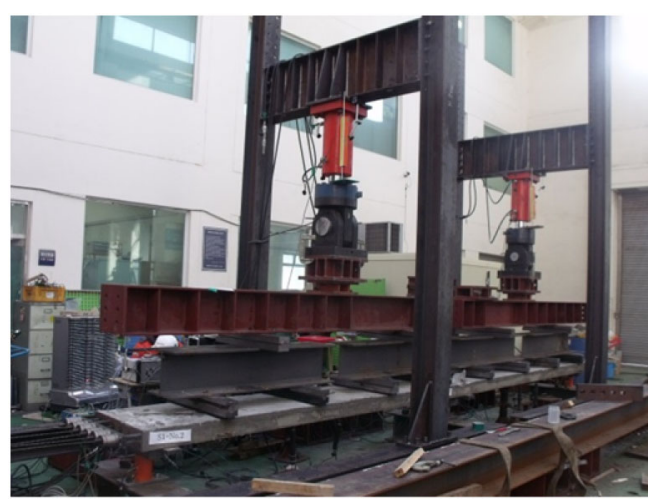

(a)

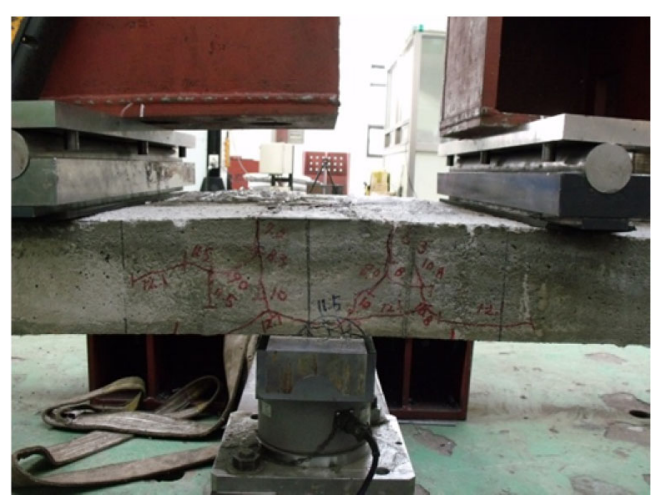

(b)

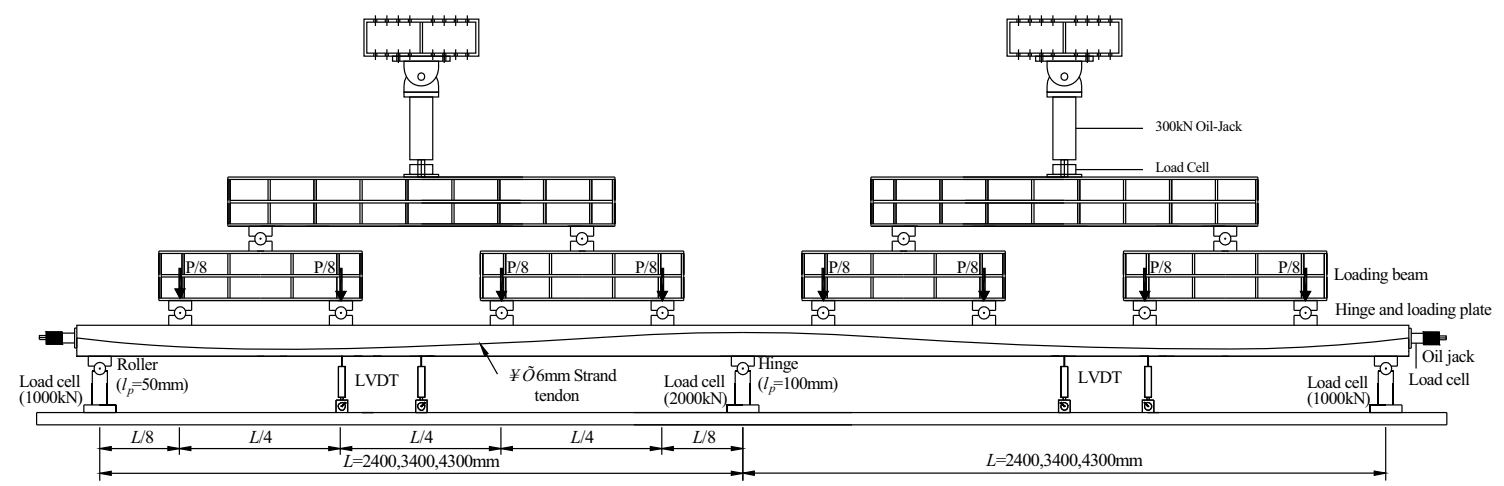

(c)

Fig. 2 Test setup a actuator and specimen b loading points and support $\mathbf{c}$ load cell and LVDT.
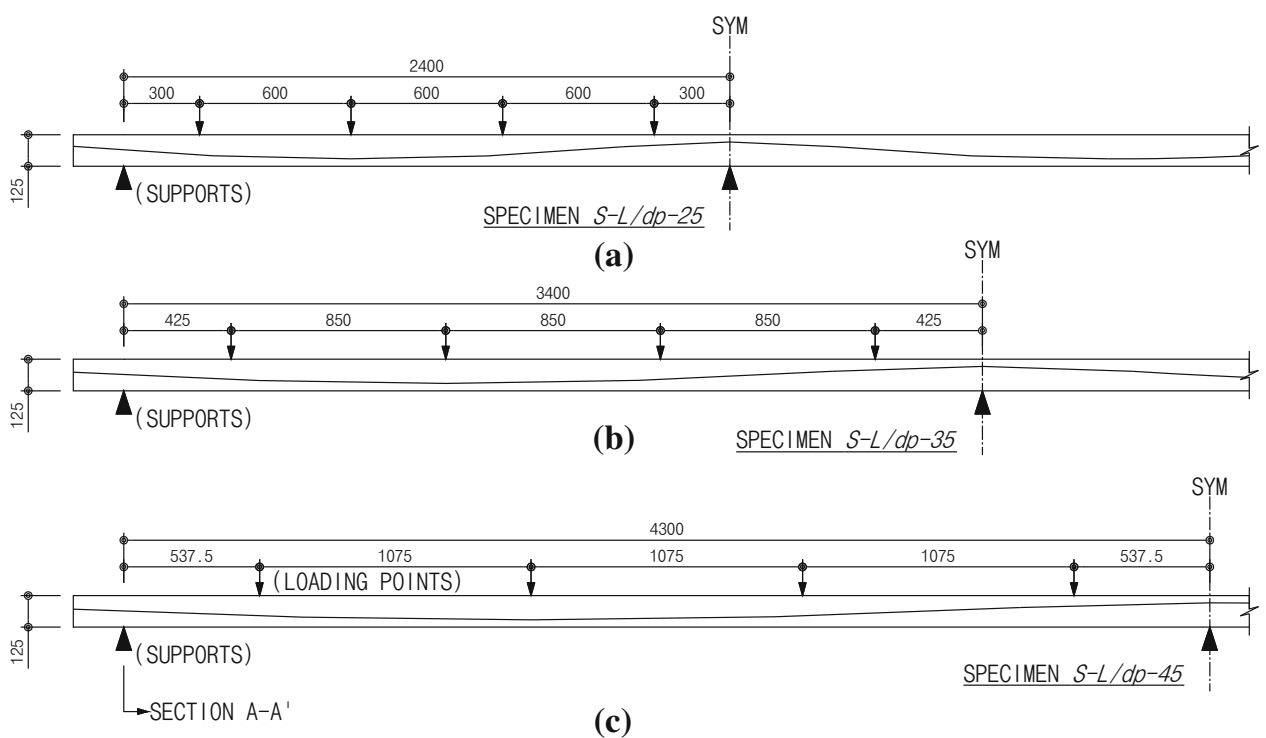

Fig. 3 Loading points and supports of a specimen $S-L / d_{p}-25$, b specimen $S-L / d_{p}-35$, c specimen $S-L / d_{p}-45$ and specimen $S-P P R$. 
rebars were used as reinforcing steel. The effective prestress of tendon $\left(f_{p e}\right)$ was $60 \%$ of its ultimate stress $\left(f_{p u}\right)$. The concrete compressive strength was $35 \mathrm{MPa}$. See Figs. 2 and 3 for their configurations.

The mixtures of LWC for the test are listed in Table 2, and the material properties of lightweight aggregates are listed in Table 3. Test results of lightweight concrete mixture are shown in Table 4. The designed compressive strength of the ready-mixed concrete using lightweight aggregates was $35 \mathrm{MPa}$ for all specimens. Artificially expanded clay granules with maximum sizes of 20 and $5 \mathrm{~mm}$ were used for lightweight coarse and lightweight fine aggregates, respectively. The lightweight fine aggregates were replaced with local natural sand by as much as $30 \%$ by volume in order to control the continuous grading. The average dry density of the mixed LWC was approximately $1770 \mathrm{~kg} / \mathrm{m}^{3}$. The mechanical properties of the steel reinforcing bars are listed in Table 5. The tensile strength and equivalent yield strength $\left(f_{p y}\right)$ of the low relaxation three-wire mono-strand were 2050 and $1852 \mathrm{MPa}$, respectively. The equivalent yield strength of the strand was calculated using measured nonlinear stressstrain curves according to ASTM A 416 (American Society for Testing and Materials 1996). The yield strengths of the mild reinforcing bars with diameters of 10 and $6 \mathrm{~mm}$ were 446 and $475 \mathrm{MPa}$, respectively.

\subsection{Test Procedure and Measurement}

Each continuous one-way slab specimen was supported on hinges at both ends and on a roller at the center. The uniform load was applied by universal testing machine (UTM) at a

Table 2 Mixture proportions of lightweight concrete.

\begin{tabular}{c|c|c|c|c|c|c}
\hline \multirow{2}{*}{$W / C(\%)$} & $V_{G}$ & \multicolumn{5}{|c}{ Unit weight $\left(\mathrm{kg} / \mathrm{m}^{3}\right)$} \\
\cline { 3 - 7 } & & Water & Cement & $\begin{array}{c}\text { Light fine } \\
\text { aggregate }\end{array}$ & $\begin{array}{c}\text { Sand } \\
\text { Light coarse } \\
\text { aggregate }\end{array}$ \\
\hline \hline 37 & 0.573 & 181 & 542 & 311 & 230 & 554 \\
\hline
\end{tabular}

$W / C$ water-cement ratio, $V_{G}$ apparent density ratio of coarse aggregate.

Table 3 Material properties of lightweight aggregates.

\begin{tabular}{|c|c|c|c|c|c|c|c|}
\hline \multirow[t]{2}{*}{ Aggregates } & \multirow{2}{*}{ Max. size $(\mathrm{mm})$} & \multirow[t]{2}{*}{ Specific gravity } & \multirow{2}{*}{$\begin{array}{l}\text { Unit weight } \\
\left(\mathrm{kg} / \mathrm{m}^{3}\right)\end{array}$} & \multirow{2}{*}{$\begin{array}{l}\text { Fineness } \\
\text { modulus }\end{array}$} & \multicolumn{2}{|c|}{ Absorption (\%) } & \multirow[t]{2}{*}{ Void ratio $(\%)$} \\
\hline & & & & & 1 day & 14 days & \\
\hline Coarse & 19 & 1.80 & 931 & 3.365 & 11.8 & 14.29 & 48 \\
\hline \multirow[t]{2}{*}{ Fine } & 4 & 1.80 & 1105 & 1.838 & 15.9 & 18.53 & 39 \\
\hline & 2 & 1.30 & 978 & 2.458 & 19.1 & 24.3 & 25 \\
\hline
\end{tabular}

Table 4 Lightweight concrete mixture test results.

\begin{tabular}{|c|c|c|c|c|c|c|c|c|c|c|c|c|}
\hline \multirow[t]{2}{*}{ No. } & \multirow{2}{*}{$\begin{array}{l}\text { Slump } \\
(\mathrm{mm})\end{array}$} & \multicolumn{6}{|c|}{ Compressive strength (MPa) } & \multicolumn{2}{|c|}{$\begin{array}{l}\text { Splitting tensile } \\
\text { strength }\end{array}$} & \multicolumn{2}{|c|}{ Modulus of rupture } & \multirow{2}{*}{$\begin{array}{c}\begin{array}{c}\text { Modulus } \\
\text { of } \\
\text { elasticity } \\
(\mathrm{MPa})\end{array} \\
E_{c}\end{array}$} \\
\hline & & 1 day & 3 days & 7 days & 28 days & 56 days & 92 days & $\begin{array}{c}f_{s p} \\
(\mathrm{MPa})\end{array}$ & $\frac{f_{s p}}{\sqrt{f_{c k}}}$ & $\begin{array}{c}f_{r} \\
(\mathrm{MPa})\end{array}$ & $\frac{f_{r}}{\sqrt{f_{c k}}}$ & \\
\hline 1 & 220 & 4.9 & 15.1 & 30.4 & 36.7 & 38.7 & 39.3 & 3.19 & 0.53 & 2.81 & 0.46 & 11,614 \\
\hline 2 & 230 & 4.7 & 13.5 & 24.1 & 29.2 & 30.5 & 31.9 & 2.62 & 0.49 & 3.15 & 0.58 & 13,442 \\
\hline 3 & 242 & 5.2 & 16.7 & 29.4 & 35.2 & 38.5 & 39.3 & 2.53 & 0.47 & 2.91 & 0.49 & 11,280 \\
\hline
\end{tabular}

Table 5 Material properties of steels.

\begin{tabular}{|c|c|c|c|c|c|c|}
\hline & Area $\left(\mathrm{mm}^{2}\right)$ & Yield strain & $\begin{array}{l}\text { Yield strength } \\
(\mathrm{MPa})\end{array}$ & $\begin{array}{c}\text { Tensile strength } \\
(\mathrm{MPa})\end{array}$ & $\begin{array}{c}\text { Young's modulus } \\
(\mathrm{MPa})\end{array}$ & Elongation (\%) \\
\hline Anchoring plate & - & - & 402 & 480 & - & - \\
\hline Tendon (3 strands) & 19.89 & 0.01000 & 1852 & 2050 & 201,319 & 5.7 \\
\hline \multicolumn{7}{|c|}{ Mild bar } \\
\hline D10 & 71.00 & 0.00279 & 446 & 639 & 214,976 & 18.4 \\
\hline D6 & 31.60 & 0.00282 & 475 & 500 & 171,121 & 3.9 \\
\hline
\end{tabular}




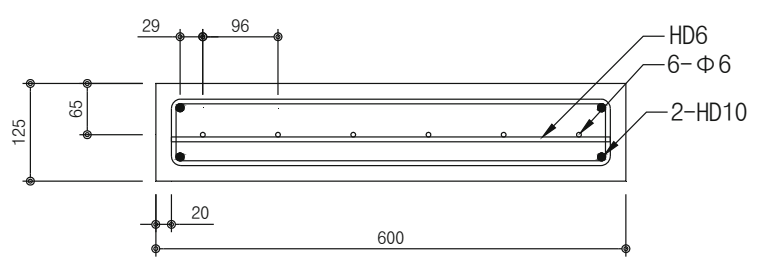

SECTION A-A'

(a) Group 1

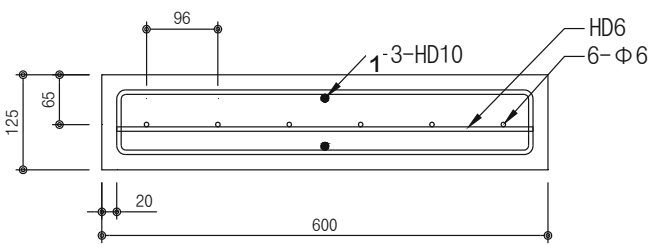

SECTION A-A'

SPECIMEN S-PPR-0.5

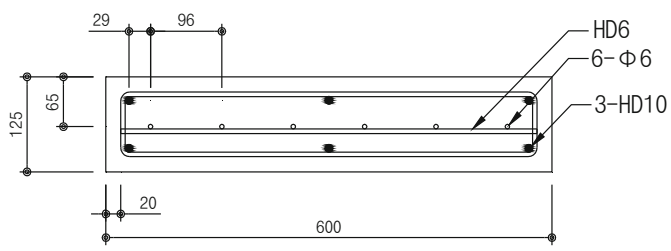

SECTION A-A'

SPECIMEN S-PPR-1.5

(b) Group 2

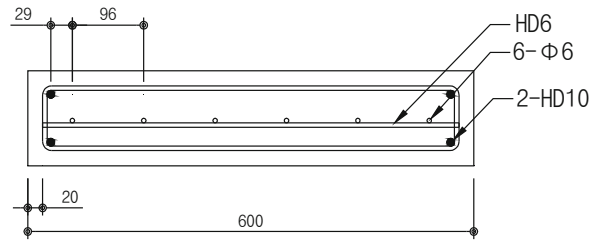

SECTION A-A SPECIMEN S-PPR-1.0

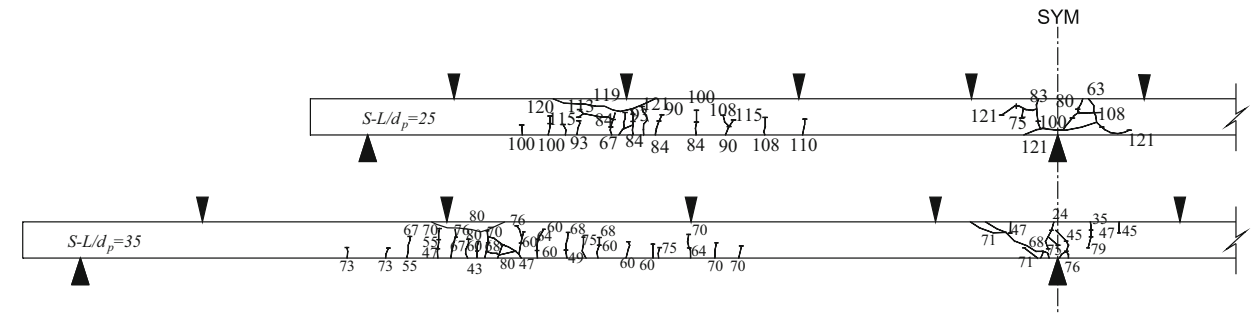

※ Specimen $S-L / d_{p}=45$ is identical with $S$ - $P P R-1.0$ of Group 2

(a) Group 1

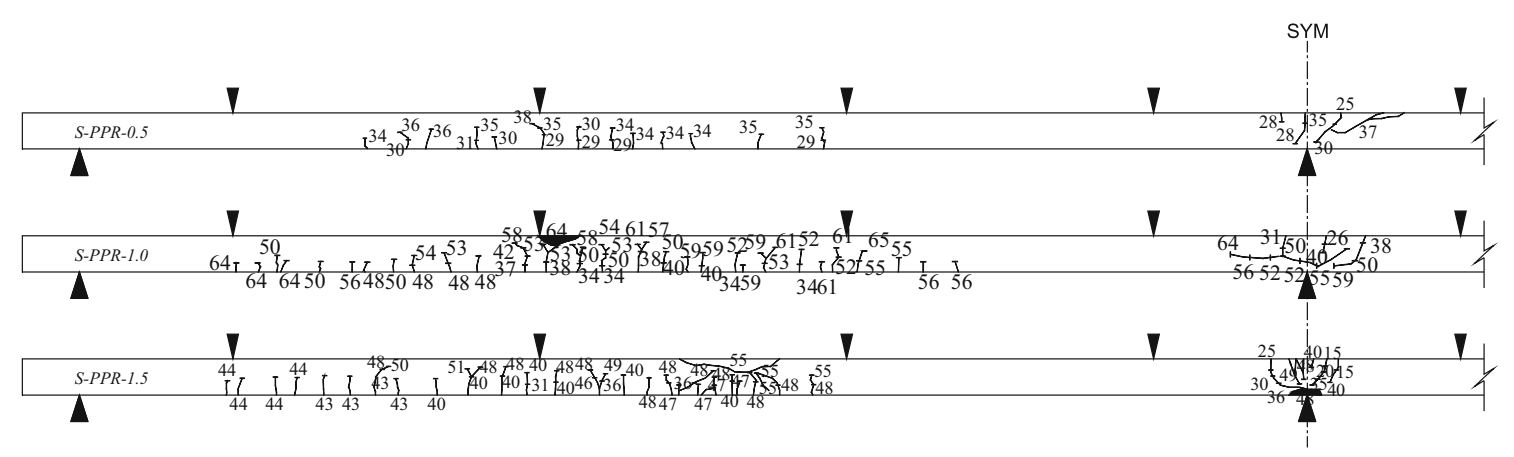

(b) Group 2

Fig. 5 Crack development of each group. 
rate of $2.5 \mathrm{~mm}$ per minute. Linear variable differential transducers (LVDTs) were installed beneath the specimens at the loading points to measure the vertical deflection (Fig. 2). The $200 \mathrm{kN}$ capacity load cells were installed on both ends of specimens to trace the stress incremental in unbonded tendons. The loading points and supports of each specimen are described in Fig. 3 and the section details are shown in Fig. 4. The crack width was measured from where the first cracks appeared until the reinforcing steels yielded. Electrical resistance strain gages were attached to the surface of the concrete and the steel to check how the strain changes, especially when concrete reached its ultimate strain (0.003). Concrete strain gages were installed on both compressive and tensile area of the center and the edges of specimens. Wire strain gages were installed on rebars at intervals of $d / 2$. All data from the UTM, load cells, and gages were collected into a data logger and saved in a computer. Through the process, the following information was obtained: crack development pattern and failure mode; load-displacement relationship; load-reaction relationship; load-tendon stress; flexural capacity; flexural ductility; and curvature-prestress loss.

\section{Test Results}

\subsection{Crack Propagation and Failure Mode}

Crack propagation patterns were marked in Fig. 5. No diagonal crack was found; that means in this test, that flexural behavior was dominant. The maximum moment occurred at the center supports of the slabs; therefore, cracks were initiated at the upper parts of the center supports (negative moment region) and then developed at the lower parts of mid-spans (positive moment region). Due to the reinforcing steels, the cracks maintained the same intervals to each other, propagating towards the middle of the spans. Upon reaching maximum loading, cracks also achieved their maximum width at the center of the spans, while cracks at the supporting areas stopped developing prior to that stage. When the simultaneous compressive fracture and dramatic flexural strength reduction was achieved the test was terminated. The crack happened at the same position of the members regardless of the $L / d_{p}$. The major cracks propagated until the peak loading was reached and then compressive fractures were triggered. With the higher $L / d_{p}$, the cracks distributed more broadly. In all specimens, only a little more crack propagations were observed after the peak loading. In Group 2, specimen S-PPR-0.5 reinforced less than $S$-PPR-1.5 showed fewer number of cracks although their width were bigger. That means specimens with more reinforcing steels are advantageous in control of crack width, although more fine cracks are expected.

\subsection{Load-Deflection Relationship}

In Group 1 , as the $L / d_{p}$ increased from 25 to 45 , the ultimate load was reduced by $44 \%$, while the deflection at the ultimate loads was increased (Table 6). Initial crack strength $\left(P_{c r}\right)$ and yield strength $\left(P_{y}\right)$ also dropped as the $L / d_{p}$ increased. As

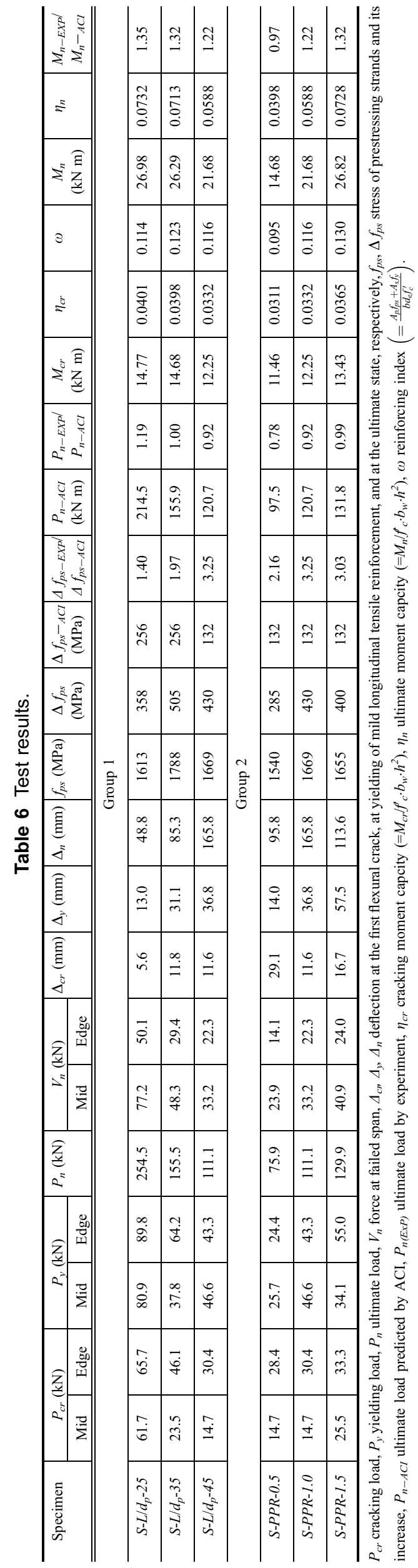




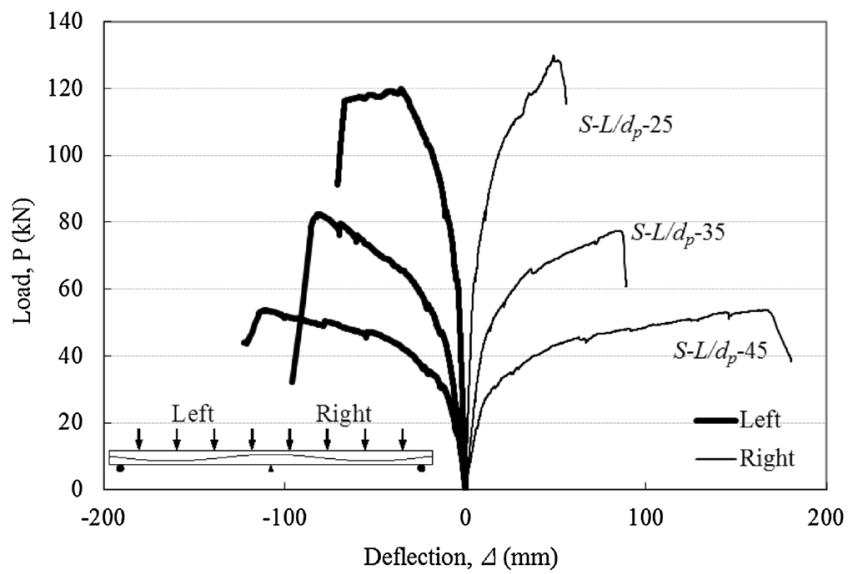

(a) Group 1

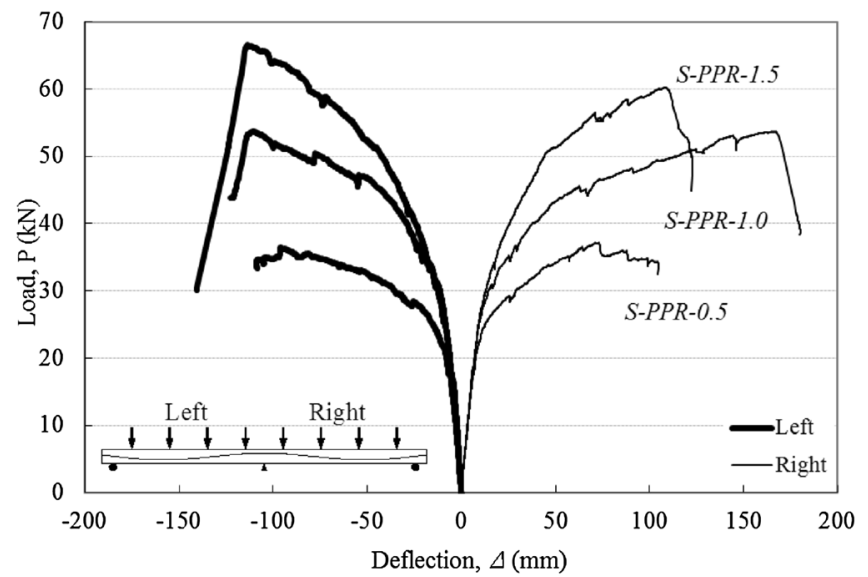

(b) Group 2

Fig. 6 Load-deflection relationship for each group.

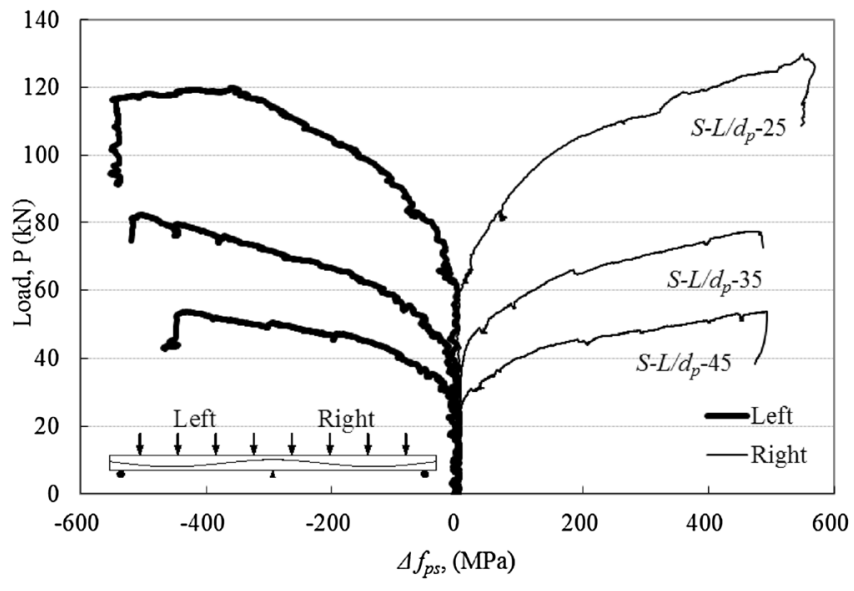

(a) Group 1

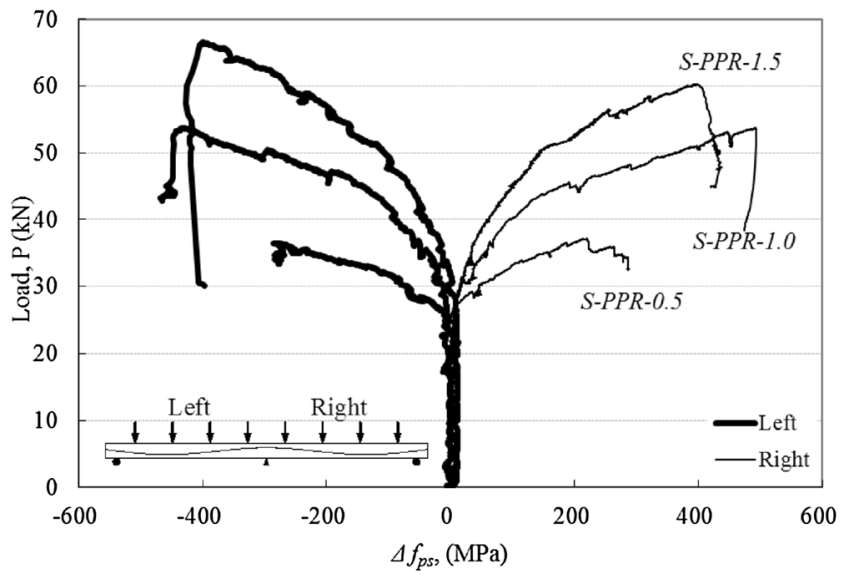

(b) Group 2

Fig. 7 Load-tendon stress relationship for each group.

Table 7 Comparison of experiments and standards for ultimate stress increment of unbonded tendons.

\begin{tabular}{c|c|c|c|c|c}
\hline \multirow{2}{*}{ Specimen } & \multicolumn{2}{|c|}{ Experimental } & \multicolumn{3}{c}{$\left(\Delta f_{p s}\right)_{\text {exp }} /\left(\Delta f_{p s}\right)_{p r e}$} \\
\cline { 2 - 6 } & $f_{p s}(\mathrm{MPa})$ & $\Delta f_{p s}(\mathrm{MPa})$ & ACI & AASHTO & CAN3 \\
\hline \hline$S-L / d_{p}=25$ & 1613 & 358 & 1.38 & 1.14 & 0.66 \\
\hline$S-L / d_{p}=35$ & 1760 & 505 & 3.79 & 2.28 & 1.32 \\
\hline$S-L / d_{p}=45$ & 1669 & 430 & 3.22 & 2.45 & 0.92 \\
\hline$S-P P R-0.5$ & 1540 & 285 & 2.14 & 2.45 & 1.42 \\
\hline$S-P P R-1.0$ & 1669 & 430 & 3.22 & 2.34 & 1.34 \\
\hline$S-P P R-1.5$ & 1655 & 400 & 2.99 & & 2 \\
\hline
\end{tabular}

shown in Fig. 6a, as $L / d_{p}$ increased, the maximum flexural strength of the slabs decreased and the ductility increased. In Group 2, as shown in Fig. 6b, specimen $S$-PPR-1.0 showed excellent ductility while specimen $S-P P R-0.5$ reinforced with the least number of reinforcement among Group 2 specimens showed compressive fracture after the reinforcement yielding. Specimen $S-P P R-1.5$ which is reinforced with $50 \%$ more steel than required was less ductile than $S-P P R-1.0$ with $17 \%$ higher ultimate load.

\subsection{Stress of Unbonded Prestressing Tendons}

The relationship of the load and the unbonded prestressing tendon stress was almost identical to that of the load-deflection. Even after reaching the ultimate loading, the tendon stresses increased continuously to bear the tension stress until the member failure. Figure 7 a shows the effect of the $L /$ $d_{p}$ on the load-tendon stress relationship. As the $L / d_{p}$ increased, the ultimate stress in tendons decreased. Figure $7 \mathrm{~b}$ shows the effects of the $\rho_{s}$ on the load-tendon stress 


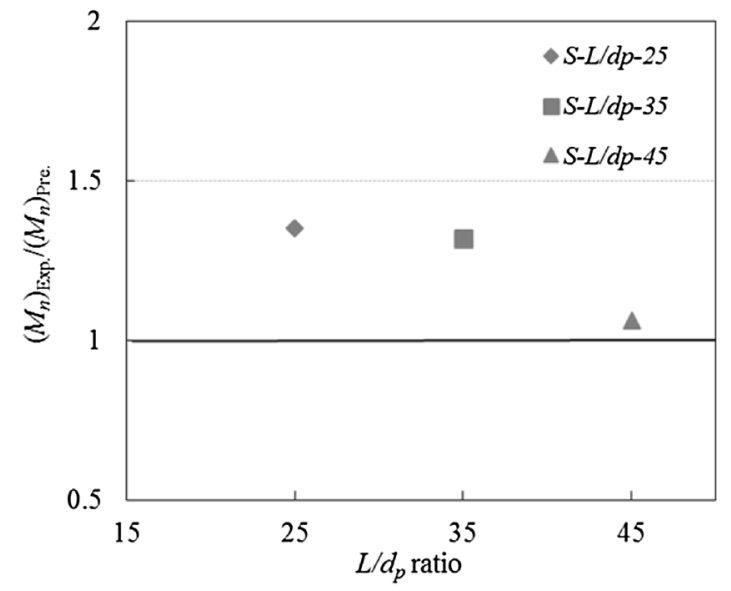

(a) Group 1

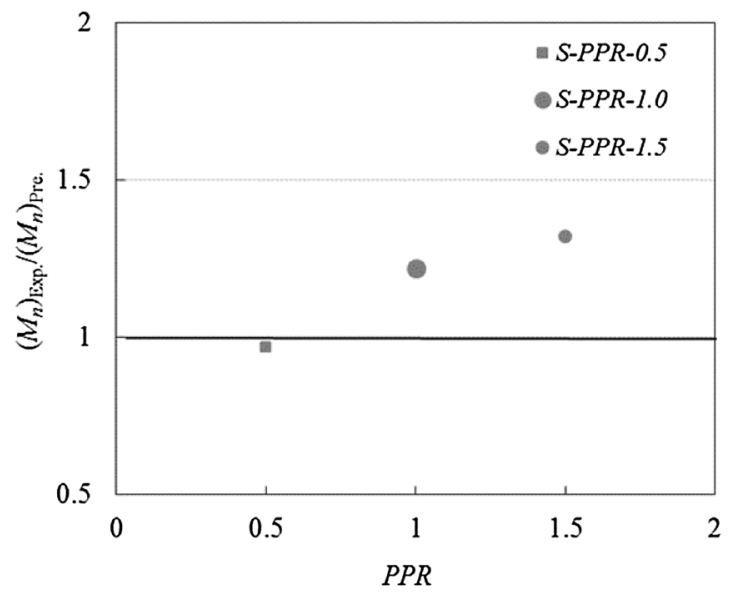

(b) Group 2

Fig. 8 Comparisons of measured and $\mathrm{ACl} 318-11$ predicted ultimate moment capacities.

relationship. All specimens in Group 2 showed similar stress increments until the initial crack happened. The maximum stress of $S-P P R-1.0$ was higher than $S-P P R-0.5$, even higher than $S-P P R-1.5$. The measured stress increase in unbonded tendons was higher than that from ACI and AASHTO (Table 7).

\subsection{Cracking and Ultimate Moment Capacities}

The normalized cracking capacities, $\eta_{c r}=M_{c r} /\left(f_{c} \cdot b_{w} \cdot h^{2}\right)$ and the ultimate moment capacities, $\eta_{n}=M_{n} /\left(f_{c}^{\prime} \cdot b_{w} \cdot h^{2}\right)$ of the specimens are listed in Table 6 . The $\eta_{c r}$ decreased as the $L / d_{p}$ ratio increased in Group 1, and a higher $\eta_{n}$ was developed with an $L / d_{p}$ ratio of 25 than those with an $L / d_{p}$ ratio of 35 or 45. In Group 2, $\eta_{n}$ increased in proportion to the $\rho_{s}$.

In Fig. 7, the ultimate moment of the specimens, $\left(M_{n}\right)_{E x p}$ is compared with the corresponding value predicted by the ACI 318-11 design procedure, $\left(M_{n}\right)_{\text {Pre }}$. The safety of the ACI 318-11 provision is significantly dependent on the reinforcing index $(\omega)$ and the loading type, but it is independent of the $L / d_{p}$ ratio. However, a moment capacity reduction was observed in the $S-L / d_{p}-45$ of Group 1 (Fig. 8a). When $\rho_{s}$ is half of the requirement, the $\left(M_{n}\right)_{\text {Exp }} /$ $\left(M_{n}\right)_{\text {Pre }}$ is less than unit (Fig. 8b).

\section{Comparison with Standards}

In Table 7, the stress in prestressing steel $\left(f_{p s}\right)$ and its increment $\left(\Delta f_{p s}\right)$ of each specimen are listed. Also, the experimental results were compared to the standards.

The mean and standard deviation of the ratios of the measured and predicted moment capacities of the post-tensioned NWC beams are 1.05 and 0.22 , respectively (Yang et al. 2013). Hence, the ACI 318-11 procedure for predicting the $M_{n}$ value of post-tensioned flexural members can be considered conservative for LWC. In other words, the ACI 318 design equations generally underestimated $\Delta f_{p s}$. The $\Delta f_{p s}$ predictions from ACI 318 are as conservative as in NWC. In addition the predictions obtained from the
AASHTO 1998 were in better agreement with the test results than ACI 318-11, showing that the mean, standard deviation, and coefficient of variation of the ratios between measured and predicted stress increases $\left(\Delta f_{p s}\right)$ are $1.70,0.53$, and 0.31 , respectively. The predictions obtained from CAN 3 were the least conservative among three standards showing that the mean, standard deviation, and coefficient of variation of the ratios between measured and predicted stress increases $\left(\Delta f_{p s}\right)$ are $1.10,0.23$, and 0.21 , respectively. The ratios of measured to predicted incremental stresses are plotted against $\omega$ accompanying with the NWC test results by Lim et al. (1999) in Fig. 9.

In all cases, $\left(\Delta f_{p s}\right)_{\exp } /\left(\Delta f_{p s}\right)_{p r e}$ for LWC is less than that for NWC. Note that $\left(\Delta f_{p s}\right)_{\exp }\left(\Delta f_{p s}\right)_{\text {pre }}$ of specimen $S-L /$ $d_{p}=25, S-L / d_{p}=45$, and $S-P P R-0.5$ in CAN 3 are less than one, while all NWC data are more than one.

\section{Conclusions}

To evaluate the flexural capacity and the ductility of posttensioned LWC continuous slabs, six specimens were tested and compared with the design standards. Through the test the followings have been found: (1) The initial crack happened at the center of negative moment and then developed at the positive moment areas on both sides simultaneously; (2) As the steel ratio in member section $\left(\rho_{s}\right)$ increased, the width of the crack decreased while the number of micro cracks increased. Also the maximum capacity increased while the ductility decreased; (3) As the span-to-effective tendon depth ratio $\left(L / d_{p}\right)$ increased, the maximum strength $\left(P_{u}\right)$ decreased. The initial crack load $\left(P_{c r}\right)$ and the yielding capacity $\left(P_{y}\right)$ also decreased while the deflection increased with $L / d_{p}$ growth; (4) As the quantity of minimum required rebars increased, the initial crack load, yielding capacity, and maximum strength increased; (5) Even after reaching the ultimate stress of flexural members, the stress in the tendons continuously increased sharing the tensile stresses. The stress increases stopped when the flexural member finally 


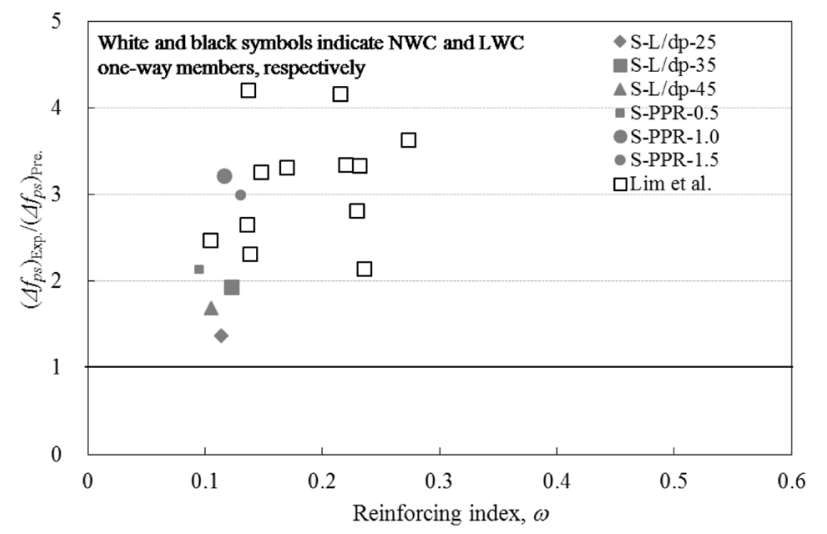

(a) ACI $318-11$

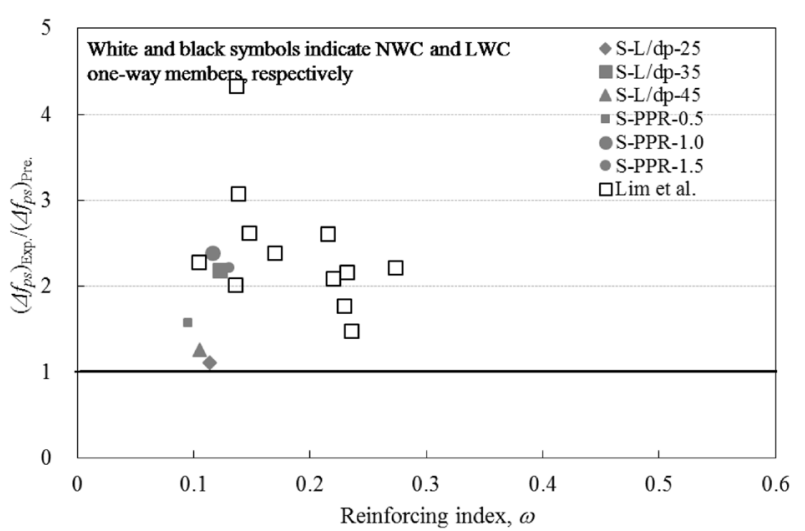

(b) AASHTO 1998

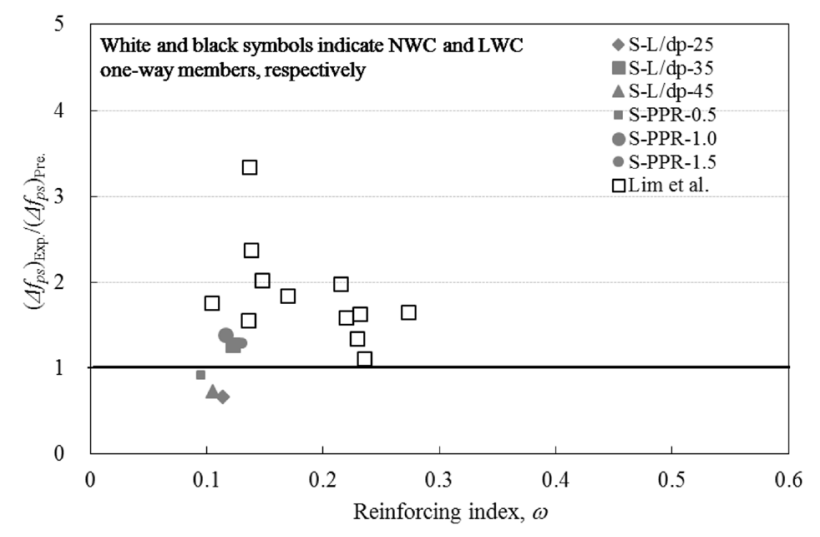

(c) Can 3-A23-M94

Fig. 9 Comparisons of measured and predictions for $\Delta f_{p s}$.

ruptured; (6) As the $L / d_{p}$ increased, the stresses in tendons decreased. That means $L / d_{p}$ is a critical factor affecting the tendon stresses; (7) In all specimens, before the initial crack, no stress change was observed in the tendons. After initial crack happened, the tendon stresses increased gradually as the applied load was increased; (8) With fewer rebars, the stress-increasing rate in the tendons was relatively high. The ACI standard evaluated the stress increment conservatively.

The expected stress increase in unbonded tendon especially by ACI and AASHTO were less than the test results in all specimens. In other words, the normalized flexural capacity of the post-tensioned LWC slabs was higher than the predictions based on the ACI code provision. The differences were not negligible quantity so it may cause overdesign.

\section{Open Access}

This article is distributed under the terms of the Creative Commons Attribution 4.0 International License (http://creativecommons.org/licenses/by/4.0/), which permits unrestricted use, distribution, and reproduction in any medium, provided you give appropriate credit to the original author(s) and the source, provide a link to the Creative Commons license, and indicate if changes were made.

\section{References}

AASHTO. (1998). AASHTO LRFD Bridge Design Specifications. Washington D.C: American Association of State Highway and Transportation officials.

ACI Committee 318. (2011). Building code requirements for structural concrete (ACI 318-11) and commentary (ACI 318R-11). Farmington Hills, MI: American Concrete Institute.

ASTM A 416. (1996). Standard specification for steel strand, uncoated seven-wire for prestressed concrete. West Conshohocken: American Society for Testing and Materials.

Au, F. T. K., \& Du, J. S. (2004). Prediction of ultimate stress in unbonded prestressed tendons. Magazine of Concrete Research, 56(1), 1-11.

Burns, N. H., Charney, F. A., \& Vine, W. R. (1978). Tests of one-way post-tensioned slabs with unbonded tendons. PCI Journal, pp. 66-81.

Cai, J., Li, G., Yang, C., \& Lin, F. (2009). Tests on unbonded posttensioned concrete flat plate with T-shaped column connections. Advances in Structural Engineering, 9(5), 671-685.

Campbell, T. I., \& Chouinard, K. L. (1991). Influence of nonprestressed reinforcement on the strength of unbonded partially prestressed concrete members. ACI Structural Journal, 88(5), 546-551.

Canadian Standards Association (Can3-A23-M94) (1994) Design of Concrete Structures for Buildings.

Chakrabarti, P. R. (1995). Ultimate stress for unbonded posttensioning tendons in partially prestressed beams. $A C I$ Structural Journal, 92(6), 689-697.

Chandra, S., \& Berntsson, L. (2003). Lightweight aggregate concrete: Science, technology and applications. Norwich, NY: Noyes Publications.

Collins, M. P., \& Mitchell, D. (1991). Prestressed concrete structures. Upper Saddle River, NJ: Prentice-Hall.

Ellobody, E., \& Bailey, C. G. (2008). Behavior of unbonded posttensioned one-way concrete slabs. Advances in Structural Engineering, 11(1), 107-120.

Harajli, M. H. (2006). On the stress in unbonded tendons at ultimate: Critical assessment and proposed changes. ACI Structural Journal, 103(6), 803-812. 
Harajli, M. H. \& Kanj, M. (1990). Experimental and analytical study of the behavior of concrete beams prestressed with unbonded tendons, Report No. CE/FSEL 90-02, University of Oklahoma, Norman, OK.

Kayali, O. (2008). Fly ash lightweight aggregates in high performance concrete. Construction and Building Materials, 22(12), 2393-2399.

Lim, J. H., Moon, J. H., \& Lee, L. H. (1999). Experimental examination of influential variables on unbonded tendon stresses. Journal of Korea Concrete Instititute, 11(1), 209-219.

Lou, T. J., \& Xiang, Y. Q. (2007). Effects of ordinary tension reinforcement on the response of beams with unbonded tendons. Advances in Structural Engineering, 10(1), 95-109.

Manisekar, R., \& Senthil, R. (2006). Stress at ultimate in unbonded post tensioning tendons for simply supported beams: A state-of-the-art review. Advances in Structural Engineering, 9(3), 321-335.

Mojtahedi, S., \& Gamble, W. (1978). Ultimate steel stress in unbonded prestressed concrete. Journal of Structural Division, ASCE, 104(ST7), 1159-1165.

Naaman, A. E., \& Alkhairi, F. M. (1991). Stress at ultimate unbonded post-tensioned tendons. ACI Structural Journal, 88(6), 683-692.
Oh, B. H., \& Choi, Y. C. (2004). State-of-the-arts of prestressed concrete structures. Magazine of the Korea Concrete Institute, 16(1), 12-21.

Ozkul, O., Nassif, H., Tanchan, P., \& Haraili, M. (2008). Actional approach for predicting stress in beams with unbonded tendons. ACI Structural Journal, 105(3), 338-347.

Tang, W. C., Lo, T. Y., \& Chan, W. K. (2008). Fracture properties of normal and lightweight high-strength concrete. Magazine of Concrete Research, 60(4), 237-244.

Warwaruk, J., Sozen, M. A., \& Siess, C. P. (1962). Investigation of prestressed reinforced concrete for highway bridges, part III: Strength and behavior in flexure of prestressed concrete beams, Bulletin No. 464, Engineering Experiment Station, University of Illinois, Urbana, IL.

Yang, K. H. (2010). Tests on lightweight concrete deep beams. ACI Structural Journal, 107(6), 663-670.

Yang, K. H., \& Mun, J. H. (2013). Flexural capacity and stress in unbonded tendons of post-tensioned lightweight concrete beams. Advances in Structural Engineering, 16(7), 1297-1310.

Yang, K. H., Mun, J. H., \& Kim, G. H. (2013). Flexural behavior of post-tensioned normal-strength lightweight concrete oneway slabs. Engineering Structures, 56, 1295-1307. 